Article

\title{
Challenging varieties of capitalism's account of business interests: Neoliberal think-tanks, discourse as a power resource and employers' quest for liberalization in Germany and Sweden
}

\section{Daniel Kinderman*}

Department of Political Science \& International Relations, University of Delaware, Newark, DE, USA

*Correspondence: kindermd@udel.edu; dpk24@cornell.edu

\begin{abstract}
This article contributes to the debate on employer preferences. It challenges varieties of capitalism's argument that manufacturing employers in Coordinated Market Economies (CMEs) will tend to defend non-liberal institutions because of the comparative institutional advantage that they provide. It examines Germany and Sweden, two critical cases in this debate. It is based on interviews with key officials and an in-depth examination of the Initiative Neue Soziale Marktwirtschaft (INSM) and Timbro, think-tanks sponsored by German and Swedish employers to shape public opinion. In line with power resource theory, I find that both German and Swedish employers have a strong preference for liberalization. In both cases, they responded to left-wing threats, institutional constraints and situations of 'crisis' by launching a counteroffensive and promoting welfare state reform, labor market flexibility and deregulation. Employers have used discourse as a power resource to pursue an aggressive liberalizing agenda and to attack institutions that required active deregulation on the part of the state. Whether employers in CMEs seek to dismantle existing institutions altogether or soften and reengineer these institutions from within, one thing is clear: their use of radical neoliberal discourse is incompatible with the claim that they defend traditional institutions in any meaningful sense.
\end{abstract}

Key words: employers, institutional change, neoliberalism, preferences, varieties of capitalism, welfare state

JEL classification: B52, D72, P16 


\section{Introduction: varieties of capitalism and liberalization theorists' views of employer preferences}

There is widespread agreement that 'employers exercise very significant power' in capitalist democracies (Thelen, 2010, p. 201), but varieties of capitalism (VofC) and its critics continue to disagree about employers' institutional preferences. Liberalization and power resource theorists (PRT) argue that employers strive to rollback welfare benefits and market-constraining regulation (Hacker and Pierson, 2004; Korpi, 2006; Amable and Palombarini, 2009; Streeck, 2009; Baccaro and Howell, 2011; Emmenegger and Marx, 2011; Paster, 2012a, 2013; Baccaro and Howell, 2017). They suggest that capitalists are 'fundamentally unruly' vis-à-vis social institutions and 'live predators ... for which politically imposed social obligations are nothing but bars of a cage bound to become too small for them and for their insatiable desire for the hunt' (Streeck, 2009, pp. 234-235).

By contrast, proponents of VofC-an approach which 'continues to have a uniquely powerful hold on the field' (Witt and Jackson, 2016, p. 780)—do not find that employers in Coordinated Market Economies (CMEs) push for competitive deregulation. At the core of VofC is the idea that employers' institutional preferences vary systematically across the Liberal Market Economy (LME)/CME divide (Hall and Soskice, 2001; Mares, 2003; Hall and Thelen, 2009; Thelen, 2014). Whereas employers in LMEs push aggressively for liberalization, employers in CMEs such as Germany derive competitive advantage from coordination. For this reason, they defend traditional institutions (Thelen, 2014, pp. 23, 30), and have 'supported only moderate reforms' (Jackson and Schnyder, 2013, p. 332) and 'patchy' rather than 'wholesale deregulation of the labour market' (Hassel, 2014, pp. 62, 77). The literature on dualism claims that employers outside of the core of manufacturing press for institutional change but maintains VofC's emphasis on conservative preferences in the core.

VofC and its critics 'disagree fundamentally about how to think about contemporary capitalism’ (Howell, 2015, p. 401). VofC proponents view the persistence of formal institutional structures of coordination ${ }^{1}$ in many CMEs as evidence supporting an updated VofC analysis. Critics view the 'convergence of institutional functioning' (Baccaro and Howell, 2011, p. 527) as undermining VofC. The debate hinges on the role of employers in core sectors in CMEs and their underlying interests: do they actively support and defend non-liberal institutions or strive to break free from these constraints on their market freedom? Is the pressure on non-liberal institutions in CMEs exogenous (VofC) or endogenous (PRT)?

This article contributes to this debate with an in-depth examination of employer preferences in Germany, a paradigmatic CME and a critical 'test case' for VofC. It focuses on a foundational pillar of VofC, 'the role that business associations ... play in the political economy' (Hall and Soskice, 2001, p. 4). It is based on interviews with leading employers' association officials and a detailed analysis of the Initiative Neue Soziale Marktwirtschaft (INSM) or New Social Market Initiative, a large-scale campaign founded and funded by the

1 More specifically: wage bargaining institutions, codetermination, works councils and the system of vocational training. 
employers' association Gesamtmetall in 2000 to shape public opinion. It extends the analysis to Sweden, 'the paradigmatic case of social democratic capitalism' (Schnyder and Jackson, 2013, p. 319), with a discussion of Timbro, a think-tank founded by the Swedish Employers Federation (SAF) in 1978. Here I draw on the insights of current and former presidents/CEOs of the organization as well as Swedish business association officials.

While most scholars are only vaguely familiar with these cases, they can help us to understand the dramatic transformations of German and Swedish capitalism during recent decades. Recent literature acknowledges the INSM, but only in passing (Streeck, 2009; Hassel and Schiller, 2010; Paster, 2012a; Silvia, 2013; Campbell and Pedersen, 2014, 2015; Fleckenstein and Lee, 2017). The same is true of Timbro, with the exception of Blyth (2001). Both initiatives can help us to understand what some employers really want; their expressed preferences appear to undermine many of the assumptions at the core of the VofC literature. The time has come for an in-depth analysis that enhances our understanding of employer preferences and institutional change in the German and Swedish political economies.

This article is organized as follows. Section 2 lays out the key arguments and some methodological remarks. Section 3 is the main empirical case. It directly challenges VofC and is divided into subsections which: explain how the INSM sheds light on German employer preferences and addresses the argument that its real purpose is to appease discontented small and medium-sized enterprises (SMEs) (3.1); discuss the INSM's origins in the late 1990s (3.2); describe the INSM's programmatic agenda (3.3); discuss the INSM's push for liberalization between 2003 and 2005 (3.4); address the INSM's apparent moderation after 2006 (3.5). Section 4 discusses what some leading officials have to say about institutions. Section 5 provides a comparative perspective. Section 6 concludes the article.

\section{Research design and key arguments}

Employers in CMEs have not defended non-liberal institutions in any meaningful sense; instead, they have used neoliberal think-tanks to soften and undermine them. In advancing this argument, this article contributes to a growing literature that challenges VofC's account of business interests (Streeck, 2009; Paster, 2012a, 2013; Baccaro and Howell, 2017; Fleckenstein and Lee, 2017). Whereas VofC sees the pressure on non-liberal institutions as exogenous, I view the pressure on non-liberal institutions as endogenous since it has been propagated by employers themselves. In both Germany and Sweden, employers' associations responded to left-wing threats, lackluster economic performance and growing institutional constraints—a situation of 'crisis' - by founding think-tanks which they have used to aggressively promote welfare state reform, labor market flexibility and deregulation. Claims that employers have an overriding preference for non-liberal institutions or that their defense of traditional institutions constrains liberalization are hard to sustain. Instead, employers have a fundamentally liberal orientation or Grundgesinnung; they prefer a reduction of benefit entitlements and constraints on market activity; and they have pursued an aggressive liberalizing agenda. If neoliberalism, 'at its essence,' 'involv[es] a commitment to certain core principles focused on market competition and a limited state' (Schmidt and Thatcher, 2013, p. 1), then German and Swedish employers' associations' orientations are neoliberal. This article suggests that it is a mistake to assume that the core manufacturing industries want to preserve prevailing institutions. Even core manufacturers can be liberalizers. 
During recent decades, employers have increasingly resorted to think-tanks to advance the cause of liberalization and 'convert business preferences into public policy ... in noisy political conflicts' (Culpepper, 2016, p. 462). Think-tanks deserve a more prominent place in comparative political economy research: they '(re)make reality' and play an important role in the "cognitive struggle "for the power to impose the legitimate vision of the social world" (Amable and Palombarini, 2009, p. 130). An examination of think-tanks helps us to understand 'the mechanisms of employer power in the advanced capitalist democracies' (Culpepper, 2016, p. 462): capital and its representatives have used radical pro-market ideas as 'weapons' (Blyth, 2001) and discourse as a power resource to resist social regulation and engage in 'a long struggle for a fundamental restructuring of the political economy of postwar capitalism' since the 1970s (Streeck, 2014, pp. 16, 27).

By 'constitut[ing crises] in and through narrative' (Hay, 1996, p. 254), both the INSM and Timbro have bolstered the economic reform and liberalization agenda in Germany and Sweden. These think-tanks have facilitated processes of conversion and layering that have led to a marked transformation of the German and Swedish social models and of German and Swedish capitalism over the past decades. Although Germany is a comparatively inhospitable environment for neoliberal ideas and policy proposals (Kinderman, 2014, p. 24), the pages below suggest that the INSM and Timbro have been politically effective in supporting the liberalization of the German and Swedish economies. This contradicts VofC's arguments concerning the role of business in politics and it has implications for the way we think about institutions and class power in political economy.

Preferences are notoriously very difficult to operationalize and impossible to observe directly. While the empirical evidence presented in this article is imperfect, it is more systematic and comprehensive than the evidence provided by proponents of VofC who in most cases simply assume these preferences based on theoretical considerations. While the INSM and Timbro are not necessarily representative of German and Swedish business as a whole, they can tell us a great deal about the interests of their founders and funders, Gesamtmetall and the Swedish Employers' Association SAF/the Confederation of Swedish Enterprise (Svenskt Näringsliv or SVN). Gesamtmetall represents employers' associations in the metalworking and electrical engineering industries-the area where VofC is most likely to apply. SVN represents the political interests of Swedish business as a whole. The existence of the INSM and Timbro suggests that there is a lot of support for liberalization of the labor market and of the welfare state in the leading sectors of the German and Swedish economies or what Amable and Palombarini (2009) call the 'dominant social bloc'.

Of course, statements made by campaigns such as the INSM and Timbro reflect a variety of motives. Like public relations (PR) campaigns, the INSM and Timbro need press coverage; and in order to get it, the staffs may sharpen some messages to incite controversy or moderate others in response to anti-market shifts in public opinion. For these reasons, statements cannot necessarily be taken at face value or as one-to-one representations of employers' underlying preferences. Some scholars have extended this line of thinking to suggest that the function of the INSM is not to represent employer interests at all, but to appease discontented SMEs within employers' associations. I examine these claims and find no empirical support for them. In order to better understand employers' underlying interests, I conducted more than two-dozen in-depth interviews with officials associated with Gesamtmetall and the INSM as well as Timbro and the SAF/SVN. A number of these officials read a draft of this article and stated that they agree 'to the greatest possible extent' and 
'to a very large extent' with the arguments made here. This increases confidence in the external validity of my findings. ${ }^{2}$

Paradoxically, the employers' associations which founded and fund these free-market think-tanks continue (to varying degrees) to engage in social partnership and collective bargaining. Thus, while employers are not the institutional patriots VofC makes them out to be, their strategy is more complex than blanket opposition and an all-out assault on non-liberal institutions. ${ }^{3}$ Gesamtmetall and the SAF made a conscious decision to outsource their neoliberal reform agenda and delegate some of the tasks of articulating and disseminating positions on institutional reform and public policy to the INSM and Timbro. Their thinking was that formal autonomy/independence would increase the legitimacy and effectiveness of these organizations, affording them greater freedom to critique the status quo and formulate combative and hard-hitting positions while allowing their principals to distance themselves from these messages if they became a serious liability in public debate. Having radical freemarket ideas on the table increases employers' menu of choices and aids their ability to reconstruct/reengineer institutions to expand employer discretion (Baccaro and Howell, 2011) as well as pursue the 'nuclear option' of dismantling them altogether. Even where think-tanks have failed to advocate for full-scale liberalization, this cannot necessarily be taken as support for the institutional status quo.

This article supports previous findings that employers' preference for liberalization is the default position (Kinderman, 2005) but goes beyond by showing the variation and dynamism in business positions over time. Examining these changes can help clarify 'how, when, where, and why ideas and discourse matter for institutional change, and when they do not' (Schmidt, 2010, p. 21). During the initial period (2000-2006), the INSM was an outspoken and influential advocate of far-reaching institutional change. It played a proactive and agenda-setting role, and many of its positions pointed beyond the Agenda 2010 reforms, to an LME-style model. But since 2006 and especially 2008/2009, the INSM's campaigns have become more moderate and defensive as it was forced to adapt to changes in public opinion and electoral politics. Following the discrediting of the Anglo-American model in the financial crisis, significant wage repression by German employees and the unexpected revitalization and resurgence of the German economy, employers have rediscovered the virtues of the (new) German model. These developments raise a series of questions which will be explored in the pages below: what explains the change in the INSM's strategies over time? And why did governments take employers' complaints more seriously in the first period than in the second one?

2 This applies to the German portion of the article. Thomas Vajna, personal communication, January 5 , 2015; Nico Fickinger, personal communication, June 11, 2014, on behalf of Nico Fickinger, Ulrich Brocker and Volcker Fasbender. Both Vajna and Fickinger made a number of suggestions for improving the article, but these were of a factual nature and did not concern the article's central argument. Regarding the Sweden section of the article, Janerik Larsson responded that 'what you write about Sweden seems fairly accurate' (personal communication, February 3, 2016).

3 Whether employers view institutions as a useful resource or a burdensome constraint depends on their specific and concrete manifestation. A fine line can separate useful resources from burdensome constraints, and institutions which from a distance appear simply as traditional CME institutions may be one or the other. Recognizing that institutions are 'highly malleable', employers have sought to reduce burdensome constraints and 'expand employer discretion' (Baccaro and Howell, 2011, pp. 522, 527). 


\section{The INSM}

\subsection{The INSM and German employer preferences}

Because the INSM is wholly dependent on Gesamtmetall, the INSM sheds light on what these German employers want. The INSM's governance structure suggests that it enjoys broad support among Germany's metalworking and electrical industries' employers' associations. The money for the INSM comes from Gesamtmetall's regional employers' associations. Its supervisory board is composed of representatives from Gesamtmetall and Gesamtmetall's regional employers' associations. Tight linkages also exist to the employer-funded Cologne Institute for Economic Research, which creates much of the content for the INSM's campaigns. In its quest to influence public opinion, the INSM uses advertisements, events, scientific studies, and an extensive online presence. ${ }^{4}$ Gesamtmetall gave the INSM a clear mandate to propagate and popularize Ordoliberal/neoliberal ideas and reforms. To date, Gesamtmetall has spent in excess of $€ 150$ million on the INSM. These are substantial sums of cash, not cheap talk. ${ }^{5}$

The INSM does have some operational autonomy from Gesamtmetall: the organization has its own staff and ambassadors, and PR and advertising companies disseminate the INSM's messages. ${ }^{6}$ Yet it is not the case that 'Gesamtmetall just pays the [INSM's] bills' (Silvia, 2013, p. 216). Instead, Gesamtmetall leads the INSM 'on a long leash' (Speth, 2004, p. 5). Gesamtmetall's executives and the presidents of all of Gesamtmetall's regional employers' associations meet periodically (3-4 times per year) the INSM staff, to assess the latter's activities and discuss priorities. The INSM's strategies are always agreed upon with Gesamtmetall, and Gesamtmetall's member associations play a very important role in determining the content of the INSM. Depending on the situation, Gesamtmetall may play a very active role and prompt the INSM to prioritize certain topics (Rath, interview, 2012). Thus, a close examination of the INSM can provide insights into the reforms that these German employers want. But perhaps is the INSM just PR and 'verbal radicalism' to appease discontented SMEs coveting neoliberalism? This explanation for the INSM can be found in many places, including on the pages of this journal (Hassel and Schiller, 2010, p. 126; Campbell and Pedersen, 2014, p. 163; Campbell and Pedersen, 2015, p. 694).

Not surprisingly, INSM staffs reject these assertions. INSM founder Ulrich Brocker claims that 'the function of the INSM was never and is not a response to intraorganizational dynamics. Instead, it is communication and advertising for rationally justifiable framework for a properly understood social market economy'. ${ }^{7}$ Nico Fickinger, formerly in charge of the INSM in Gesamtmetall and now the managing director of Nordmetall, states that 'it was never the purpose of the INSM to placate dissatisfied firms or keep them within associations, but only to create a favorable environment for necessary market-oriented reforms'. ${ }^{8}$ My interviewees point out that the central impetus for the INSM came from large internationalized German companies with foreign supply chains in the export-oriented, high-value added sectors of the economy (Fasbender and Engemann, interviews, 2013). INSM campaigns were also discussed in detail in the Gesamtmetall committees

4 See www.insm.de, Accessed on November 23, 2016.

5 Annual expenditures are in line with the annual lobbying budgets of top companies and lobbyists in the world's lobbying capital, Washington DC

6 2000-2009: Scholz \& Friends, 2009-2014: Serviceplan, 2015-: Blumberry.

7 Ulrich Brocker, personal communication, July 6, 2013.

8 Fickinger, personal communication, June 11, 2014. 
for PR, where Siemens and Daimler had a major presence. Daimler-Benz's manager Günther Fleig was heavily involved, and Siemens, Bosch, BMW and Opel even sent their top PR people. ${ }^{9}$ If the INSM was created to placate the Mittelstand, it should figure prominently in the INSM's PR campaigns, but a negligible proportion of the INSM's press releases mention the Mittelstand. All of this casts doubt on claims that the INSM was created to appease the Mittelstand and supports the argument that 'the impetus for liberalization ... [comes] from the export sector itself' (Baccaro and Howell, 2017). Space constraints prevent a more indepth discussion of this issue (for more details, see Kinderman, 2014, pp. 7-8).

\subsection{The origins of the INSM in the late 1990s}

We were at a dead end [in einer Sackgasse] ... there were more and more recessive tendencies

—Volker Fasbender, managing director of Hessenmetall (interview, 2013). Political and economic considerations led Gesamtmetall to set up the INSM. By the mid1990s, the survival of the German model was in question: Germany was mired in 'a deep structural crisis' (Creutzburg, interview, 2013) and a 'catastrophic equilibrium' of rising unemployment and high non-wage labor costs (Dyson, 2005). A climate of Reformstau lay over the whole country, and deteriorating economic conditions led to growing discontentment in the business community (Streeck, 2005).

According to the INSM's founders, rising levels of social protection were the underlying cause of these pathologies (Brocker and Fasbender, interviews, 2013). As Brocker, founder of the INSM and former managing director of Südwestmetall and Gesamtmetall recalls, 'contributions to unemployment insurance became more expensive, competition was growing and the pressure became harder .... Eventually the advantages that Germany enjoyed were used up' (interview, 2013). But instead of addressing these problems, politicians sought to please voters with costly new welfare-state programs. Employers failed to halt the implementation of long-term care insurance in the early 1990s, which 'catalyzed [employers'] strategic reorientation from accommodation to assertiveness.... Employers realized ... [that] they had to try to define the reform agenda proactively' (Paster, 2012a, p. 168).

For Brocker, the 1996 conflict over reductions in sick pay was clear evidence of the public's hostility to reforms (interview, 2013). Unions protested, and the SPD vowed that they would reverse the cuts-which they did once in office. The public's hostility toward reforms contributed to Helmut Kohl's 1998 election loss. The views of the general population and of companies were drifting further and further apart. As a result of this growing unhappiness in the business community, the INSM could have been founded as early as the mid-1990s (Fasbender, interview, 2013); but a public opinion poll in the summer of 1999 proved decisive. The poll showed that German citizens mistrusted the market, supported a generous welfare state, were fearful of upcoming economic reforms and favored a 'third way' between capitalism and socialism (Speth, 2004, p. 7).

Gesamtmetall founded the INSM to boost their preferred reform agenda and 'halt the decline/demise' (Niedergang) of the country which was underway (Fasbender, interview, 2013):

9 Vajna, personal communication, March 1, 2015. These firms are also at the core of the Dependent Market Economies in Central and Eastern Europe (Nölke and Vliegenthart, 2009). 
Beginning in the 1960s there was an increasing entitlement mentality, more and more demands on society and less and less individual responsibility. The point [of the INSM] was to connect the social market economy with the essentials of entrepreneurial activity: competition, competitiveness, flexibility. All of this contradicts welfare state thinking that focuses on protection, excessive rigidity [Betonierung], and all that (Brocker, interview, 2013)

There was also a political dimension. Employers were concerned that Chancellor Gerhard Schröder's newly elected Red-Green government, with its left-wing finance Minister Oskar Lafontaine, would pursue an anti-business and redistributive agenda. The INSM was founded to ensure that even under a Red-Green government, employers could pass laws that are business-friendly. On June 1, 2000 the INSM began its work.

\subsection{The agenda of the new social market economy}

The INSM campaign is entitled the 'neue soziale Marktwirtschaft'- the 'New Social Market Economy'-although its goal is to restore the 'old' social market economy (Kinderman, 2005). The social market economy is the founding myth of the Federal Republic of Germany (Haselbach, 1997). For the Ordoliberals in the 1950s, the term stood for the view that freemarket competition is the best way to achieve social goals (Paster, 2012a). The prominence and currency of 'social market economy' discourse in Germany is remarkable: '[t]he tale of the "social market economy"... is referred to almost every day, somewhere in a German newspaper or political statement; it has become part of the national memory' (Haselbach, 1997, p. 161). The genius of the 'social market economy' lies in its versatility: it is both 'social' (fair/just) and a '[capitalist] market.' The INSM is focused on the disjuncture between the historically evolved social market economy and its ideational origins. As Ptak points out,

Since the trade unions and the Social Democratic Party learned to use the concept in the same opportunistic way as ordoliberals, persuading governments to expand the welfare state under continuous reference to the social market economy, the model increasingly lost its original neoliberal content (2009, p. 125)

The INSM has sought to move Germany's discourse, policy and institutions closer to the social market economy's Ordoliberal origins. Just as Ordoliberalism's founders 'were hostile in principle toward social welfare as a state responsibility' (Haselbach, 1997, p. 172), the INSM is suffused with a thoroughly liberal ethos: 'freedom is the central value of the Social Market Economy' (Fasbender, interview, 2013). While many German citizens associate the social market economy with the welfare state, the INSM's founder Ulrich Brocker states that he is 'for the social market economy but against the welfare state' (interview, 2013).

The book Chancen für Alle is one of the INSM's central texts. It was written by Randolf Rodenstock, president of the Bavarian employers' and metalworking industry association, vice-president of Gesamtmetall and a member of the Mont Pèlerin Society. The book is centered on the idea of equality of opportunity in free markets, a distinctly liberal worldview which seems quite appropriate for an LME, but is hard to reconcile with Bismarckian status maintenance and VofC's vision of long-term investments in firm-specific skills. Rodenstock praises the USA and suggests that Germany should model itself on America's flexible labor and product markets and low levels of regulation. Because the social market relies on efficient self-regulation, it only needs a minimum of ethics and rules. Market distorting institutions are unnecessary and counterproductive because the market itself is fair and just: it 
rewards performance and is based on equality of opportunity (Rodenstock, 2001, pp. 25, $28,178)$.

Rodenstock emphasizes the need for flexiblization and deregulation in general, and of labor markets in particular; and the creation of jobs as the overriding goal of social policy and the principal requirement of social justice. 'Badly paid jobs are better than none at all. ... A guiding principal of the new social market economy is the motto: Just is whatever creates employment' (Rodenstock, 2001, pp. 54-55). This motto has had a significant impact on German public debate and on public policy. In 2002, the INSM made it the focus of a large-scale advertising campaign. 'The purpose of this initiative was to redefine the term "social" out of the widespread, but one-sided orientation towards government redistribution' (INSM, 2009). In the fall of 2002, this motto was used by CDU/CSU and FDP politicians before Wolfgang Clement, then minister of labor and economics for the SPD, adopted it. This motto pervaded the public debate and media coverage of the reform agenda; it would not be an exaggeration to say that it became the more or less official slogan of the Agenda 2010 labor market reforms (Höfer, 2010, p. 24). It is seldom recognized that this influential motto was popularized by the INSM. The fact that it was adopted by so many politicians and became closely associated with government policy illustrates employers' use of discourse as a power resource. ${ }^{10}$

Former Bundesbank president and first INSM chairperson Hans Tietmeyer's statements are hard to reconcile with the view that German employers are opposed to liberalization. In an early INSM publication, Tietmeyer explicitly refers to a Systemwechsel or change of economic model, and makes clear where the journey should go: 'the New Social Market economy is equivalent to the Anglo-Saxon, the American principle.' Tietmeyer stresses that the road ahead will not be easy: 'the necessary reforms and cutbacks will entail social hardships' and 'bitter medicine' (2001, pp. 8, 22). In 2003, the INSM challenged trade unions with the motto 'Less welfare state means more jobs', and by declaring May 1 to be the day to create jobs through supply-side reforms. In 2004, the INSM placed a sign that read: 'It's high time for reforms: GERMANY' at a prominent place in the Spree river in Berlin. The sign was hung so that GERMANY was half submerged under the water, to symbolize the gravity of Germany's situation. The INSM criticized co-determination, employment protection legislation and labor market regulation-the central institutions of the CMEs-and complained that 'Kohl lacked the courage for radical reforms along the lines of Reagan in the USA or Thatcher in the UK' (Hahne, 2005, p. 13). This evidence should be unsettling for scholars who believe that German employers depend on these institutions for their competitive strategies and defend them against political attacks.

\subsection{Pressing for liberalization: The INSM from 2003 until 2005}

From 2003 until the 2005 election, there was widespread agreement on the necessity of liberalization and welfare state reform in the German political establishment. Employers were less constrained by electoral politics during these years than at perhaps any other time in post-war German history. The INSM 'had public opinion leadership', recalls Max Höfer,

10 To clarify: I am not claiming that this discourse became dominant only because of the INSM: this discourse was 'in the air' and there were other national actors and international organizations (such as the EU) promoting it. Even so, it is impossible to deny that the INSM significantly boosted this discourse. 
one of the INSM's former directors (interview, 2013). This allows us to see if employers played an agenda-setting role or simply responded to reform initiatives by other actors. If VofC is correct and employers have structurally conservative employer preferences, they should have cautioned politicians from liberalizing too much as this would undermine the institutional foundations of their competitive advantage (Hall and Soskice, 2001, p. 58; Wood, 2001; Thelen, 2014, p. 19). But if liberalization theorists are right, employers should press for fundamental liberalization. I find that employer positions more closely approximate to the latter position than the former.

From 2003 until the 2005 elections, employers clearly supported the CDU and FDP, which had criticized the Red-Green government for adopting too few reforms and too little liberalization. The first few months of 2003, when Schröder announced his Agenda 2010, represent 'a decisive turning point in the history of the semisovereign German state' (Streeck, 2005, p. 163). The INSM facilitated these developments:

\footnotetext{
We in the INSM had devised the central slogan of the Agenda 2010: 'sozial ist, was Arbeit schafft' (just/fair is whatever creates work), and organized a broad platform of politicians, that supported the slogan: Wolfgang Clement, Olaf Scholz, Fritz Kuhn, Wolfgang Schäuble and Guido Westerwelle .... The credo, 'sozial ist, was Arbeit schafft' redefined the word 'sozial': until then, the word meant that the state spent more money on students, on social assistance, on families, etc. The high unemployment forced us to rethink this: a job helps people more than social assistance (Höfer, 2013, p. 184).
}

In a 2003 newspaper column, INSM representative Tietmeyer wrote: 'Germany needs farreaching market-oriented reforms. If necessary, these need to be implemented despite disagreement with influential interest groups and parts of the [SPD's] own party' (2003). This statement was made just 3 weeks before Schröder's famous Agenda 2010 speech. In another column just 1 month later, INSM representative Oswald Metzger expressed that the 'necessary retrenchment of the unaffordable welfare state will take until the end of the decade' (Metzger, 2003). At an INSM-organized event in the fall of 2003, Friedrich Merz of the CDU's business wing stressed the need for far-reaching reforms of the labor market, social transfer systems, the social safety net, the tax system and the education system-'in sum almost excessive demands for politicians and citizens. But there is no alternative' (Merz, 2003, p. 22). These examples illustrate the tight linkages between the INSM's campaigns and the Agenda 2010. In the words of Höfer, 'We did Schröder's PR' (interview, 2013). The INSM was influential during these years. In one session of the influential talk show 'Sabine Christiansen,' three of the five guests were affiliated with the INSM; and between 2003 and 2008, over 120 media statements per day were attributable to it (INSM, 2009).

The INSM also facilitated the CDU's turn towards more market-friendly policies. The CDU's 2003 Leipzig party convention agenda has been characterized as 'pure market culture' and as 'the most market radical program in the party's history ... catapulting [Merkel's] party into Anglo-Saxon capitalism' (Kessler, 2011). The CDU and FDP's positions from the Leipzig party convention leading up to the 2005 Bundestag elections were far more radical than those typically analyzed by VofC scholars. The latter claim that employers 'since the early 1980s have repeatedly failed to bite when presented with the carrot of deregulation' (Wood, 2001, p. 408) and 'had little interest' in a health insurance model which would call 'for employers' exit from financing health insurance altogether and substituting parity financing with compulsory, individual insurance born solely by workers' 
(Giaimo, 2001, p. 354). But in the early 2000s, the INSM favored a transition to flat-rate health contributions to lower non-wage labor costs: a 'paradigm shift' in Germany's social policy and a departure from the trajectory of the past 120 years (Merz, 2003, p. 18). It is revealing that instead of cautioning overzealous politicians from jumping on the neoliberal bandwagon, 'many top managers and entrepreneurs were enthusiastic about Merkel's 2003 Leipziger Parteitag agenda' (Balzer et al., 2008). They wanted to go further than the Hartz Reforms, for example, by eliminating employment protection and by further reducing nonwage labor costs (Fleig, interview, April 7, 2015): they were not satisfied with the rate and extent of liberalization.

In 2005, the INSM proclaimed that 'Germany needs a comprehensive program of market-oriented reforms that goes considerably beyond the Agenda 2010' (INSM, 2005a, p. 8). The INSM praised Margaret Thatcher for not letting adverse circumstances or 'fierce distributional conflicts' take her off the path of reforms (INSM 2005b, p. 47), and cited New Zealand, the UK, the USA and Sweden as examples of successful welfare state reforms. The INSM also praised Ronald Reagan's deregulation and tax cuts and Sweden's decentralization of wage bargaining in the early 1990s (INSM, 2005b, p. 48). INSM-affiliated economist Ulrich van Suntum exalted Thatcher's radical reforms and lamented that these would not be possible in Germany's political system (2006, pp. 132-133). Claims that 'support for the welfare state is much broader, reaching deep in the business community' (Mares, 2003, p. 265) are hard to sustain in light of this evidence. If that were really the case, Gesamtmetall would not fund a large-scale PR campaign that praised radical welfare state retrenchment and advocated flat-rate health insurance, a 25\% flat-rate income tax and other forms of the individualization of risk. If VofC were correct the INSM would not attack unemployment insurance, as comprehensive unemployment insurance is seen as a cornerstone of the German model by VofC advocates. Nor would they choose staff members to direct the INSM who, inspired by public choice theory, propagate the reduction or elimination of employment protection and the far-reaching flexibilization of labor markets (Enzweiler, 2013). ${ }^{11}$ But the INSM did all these things and more.

The mid-2000s presented employers with a larger liberalization carrot than ever before in the post-war period, which many wanted to bite. The language used by the INSM was that the Agenda 2010 was no more than 'a step in the right direction', and further reforms were demanded: 'according to the "hawks" in Gesamtmetall, the INSM should attack the state and unions. Schröder's Agenda 2010 did not go far enough'. While I can only speculate on the preferences of individual managers, there is reason to believe that a number of them were outspoken and radical proponents of liberalization: within Gesamtmetall, the INSM's neoliberal campaigns reportedly received the loudest applause. ${ }^{12}$

11 Tasso Enzweiler was one of the INSM's managing directors between 2002 and 2006. Although no longer affiliated with the INSM (he has gone into the consulting business), Enzweiler's doctoral dissertation was supervised by Ulrich van Suntum, an academic economist who has been associated with the INSM since its beginnings. Entitled 'Ways out of the Reform Log-Jam' (Enzweiler, 2013), his dissertation is built on public choice foundations: labor market regulations, employment protection and CME institutions are not instruments for comparative institutional advantage. Instead, they provide insiders with rents and impede market functioning.

12 Anonymous source close to Gesamtmetall, personal communication, March 5, 2014. 
But voters had had enough. By the summer of 2004, Angela Merkel's Leipziger Parteitag Agenda was coming under considerable pressure from within the CDU: $56 \%$ of CDU voters wanted the party to move in a more 'social' or moderate direction while $31 \%$ favored 'radical reform'. In the Spring of 2005, Merkel's CDU/CSU had hit $45 \%$ in the polls, but in the September Bundestag election, Merkel received only 35\% of the vote-a 'traumatic defeat' and just marginally more than Schröder's SPD (Clemens, 2007, pp. 234, 239). Not employers but public opinion constrained reforms.

VofC suggests that during the period of Hartz and Agenda 2010 reforms, German employers should have cautioned overzealous politicians against too much liberalization. They did not. Instead, they became 'a force for the liberalization of the welfare state and of labor markets' (Paster, 2012a, p. 160). Meanwhile, industrial relations institutions and firms were undergoing far-reaching changes. Fleig describes advancing the reform agenda without completely undermining the existing system of social partnership as 'a tightrope walk' and 'like dancing on a razor's edge'. Following IG Metall's defeat in the 2003 strike over workingtime reduction, he recalls that some employers wanted to 'let the unions run against the wall' and crush them (interview, 2015). The fact that they didn't does indicate some support for traditional institutions-but this is not a defense of traditional institutions in any meaningful sense. If the CDU/CSU and the FDP had won a majority in the 2005 elections, they would likely have likely legislated further liberalization with the support of employers, with farreaching implications for the German model and for VofC. The fact that this did not occur is a contingent result of electoral politics. This agenda failed because it was not conducive to the formation of a dominant social bloc (Amable, 2016) rather than because it lacked employer support.

\subsection{The moderation of the INSM since 2006}

The INSM's phase of moderation beginning in 2006 is a hard test for my argument. In this section, I argue that it is the result of a shift in the political opportunity structure. As the political winds shifted to the left, the INSM was forced into an increasingly defensive position: instead of proactively influencing public opinion, it had to adapt. In the early 2000 s, there was a political consensus on the necessity of reforms (even if these were contested by the rank and file). Through the INSM, German employers acted as motors of the liberalization process: 'all important reform topics were on the table' (Tietmeyer, interview, 2006). ${ }^{13}$ Within 10 years the situation underwent 'a complete reversal - it's unbelievable' (Creutzburg, interview, 2013).

While the 2005 election results and the resulting CDU-SPD coalition government were widely seen as a referendum against reforms, the blowback began with the so-called 'Montagsdemonstrationen' protests against Hartz IV in 2004. This sentiment grew when SPD Chairman Müntefering described private equity firms as 'locusts'. The successful establishment of Die Linke to the left of the SPD was another sign of growing resistance. Elites had failed to win over citizens' emotions for their reform agenda, and many came to perceive

13 The Pforzheim collective bargaining agreement took place against the background of threats by both governing and opposition parties to legislate opening clauses in collective agreements, if the social partners would not agree to them voluntarily. There was widespread mistrust in collective bargaining; BDI-president Michael Rogowski declared that collective bargaining agreements should be burned. 
the Agenda 2010 labor market reforms as unjust. ${ }^{14}$ In the words of NRW Metall's Hubertus Engemann, 'reforms were going in the right direction ... but then the societal mainstream shifted to the left' (interview, 2013). Axel Rhein, director at IW Medien, states that the INSM needs a megaphone in order to be heard in public debates. From 2000 until 2005, the INSM's campaigns resonated in the media and in the CDU/FDP opposition, which, in turn, amplified the INSM's messages. This resonance disappeared under the grand coalition (interview, 2014).

These developments made the INSM's work more difficult and necessitated a strategic reorientation. From 2000 to 2005, the INSM's negative campaigning style greased the wheels of liberalization. Following the 2005 elections and the formation of the CDU-SPD coalition, the INSM's campaigns became more moderate. In 2006, their focus was on promoting economic growth; in 2008, it was on increasing labor market participation; and in 2009 , the INSM celebrated the virtues of the social market economy. The INSM placed more emphasis on defending existing reform achievements than on pushing for further liberalization. An environment in which 'reform politics aren't mainstream anymore', the INSM's current director Hubertus Pellengahr told me, demands a different approach than one in which reform proponents can play an agenda-setting role (interview, 2013). After the Agenda 2010, 'the wind was taken out of our sails. The topics were no longer perceived as being so urgent and conspicuous' (Rodenstock, interview, 2013). The INSM suffered setbacks in the battle for discursive hegemony and was unable to detach 'a large enough portion of the social democratic and trade union opinion from their version of common sense' (Bruff, 2008, p. 156).

The financial crisis that began in 2008 compounded the INSM's problems and threatened to terminate it: it was unclear what discretionary expenditures Gesamtmetall would be able to sustain as the bottom fell out of the global economy. With the rapid recovery of Germany's export markets, these financial concerns faded into the background. While the INSM's operational budget was reduced, Gesamtmetall's willingness to sustain this expenditure even during hard times attests to the INSM's importance for its founders and funders.

Growing societal antipathy toward markets turned out to be a more serious problem. The financial crisis terminated the Reformdebatte, the push for market-oriented reforms: 'From 2000-2005 we had the wind of history behind us. That changed with the financial crisis. We had a new field of debate' (Höfer, interview, 2012). The INSM had been pushing for comprehensive liberalization but 'forgot the deregulation of financial markets' (Höfer, interview, 2014). In response to the financial crisis, the INSM retreated to a more moderate Ordoliberal position to prevent the market order itself from being made responsible and coming under attack: 'The INSM had to react to these changed circumstances to avoid being labeled as radically neoliberal, as further demands for reforms would have been rejected as excessive and unrealistic' (Rath, interview, 2014). With the onset of the financial crisis, business's discursive power declined, and their preferred neoliberal model was delegitimized.

For the INSM, the ambiguity of the ideational construct 'social market economy' turned out to be a blessing, for it could now present itself as an alternative to the very same

14 Trade union and civil society efforts in opposition to radical neoliberal campaigning, such as the establishment of LobbyControl in 2005, may have contributed to this shift. 
neoliberal economic policies it had itself advocated just a few years earlier. ${ }^{15}$ With the financial crisis, the Anglophone neoliberal model had lost its luster and 'had become massively discredited' (Schulze-Cleven and Weishaupt, 2015, p. 282). This suggests that there may be inherent contradictions in the INSM project. By invoking the social market economy there is always the possibility that INSM ideas will come up against more firmly entrenched conceptions of the social market economy which are more social than the INSM's worldview. The notion of Ordnung, which is part of both Ordoliberal and social democratic conceptions of the social market economy, militates against the full realization of the INSM agenda.

In May 2009, in the midst of the US subprime crisis, the INSM hired an actor to play Ludwig Erhard, father of the social market economy, and convey the message that Germany's social market economy is a model for the USA. A large banner ad on Wall Street read: 'Germany invented Aspirin for your headache. We also got something for depression: Social Market Economy.' The message was that 'American market fundamentalism can learn a great deal from the social market economy. We must return to these rules' (Höfer, 2013, p. 25).

Meanwhile, the INSM was busy defending Schröder's Agenda 2010 against politicians clamoring to reregulate markets. My interviewees express admiration for Gerhard Schröder's reforms and a general preference for bourgeois parties. However, they have deep reservations - and in many cases overtly hostile attitudes-toward Angela Merkel's governments for rolling back existing reforms and failing to pursue new ones. As the tide turned against the market, the INSM ended up campaigning against all the major parties who were seeking to roll back the Agenda 2010.

'Firms are afraid that the [Agenda 2010] reforms will be taken back', Pellengahr remarked prior to the 2013 Bundestag elections (interview, 2013). These fears have come to fruition with the introduction of a statutory minimum wage, which has effectively reversed a decade of labor market reforms. The INSM campaigned hard against this legislation, and its passage represents a clear defeat for the INSM. Political debates in Germany have moved more and more onto the terrain of justice-inhospitable territory for business because of its association with anti-market and redistributive politics. The INSM has stayed true to its founding ideals, and its recent campaigns criticize the push to regulate temporary employment contract work.

There appears to be a relationship between economic conditions and the INSM's positions and influence over the reform agenda. Figures 1 and 2 show Germany's growth and unemployment rates and major INSM campaigns. The darker shading indicates a more proactive and agenda-setting role for the INSM whereas the lighter shading indicates more reactive and defensive campaigns.

The INSM's influence was greatest during the period of high unemployment and low growth rates in the early to mid-2000s, which underlines that crises can be moments of opportunity for liberalizers and 'business influence correlates with perceptions of economic crisis' (Paster, 2015, p. 8). The Great Recession of 2009 is a notable exception. To sum up, it appears that party politics, the public opinion climate and economic circumstances influence the programmatic positions and the ability of neoliberal campaigns such as the INSM to

15 If the INSM had been based on a different concept-for example, Ordoliberal Walter Eucken's idea of a Wettbewerbsordnung or 'competitive order'-its popular legitimacy would be harder to defend. 


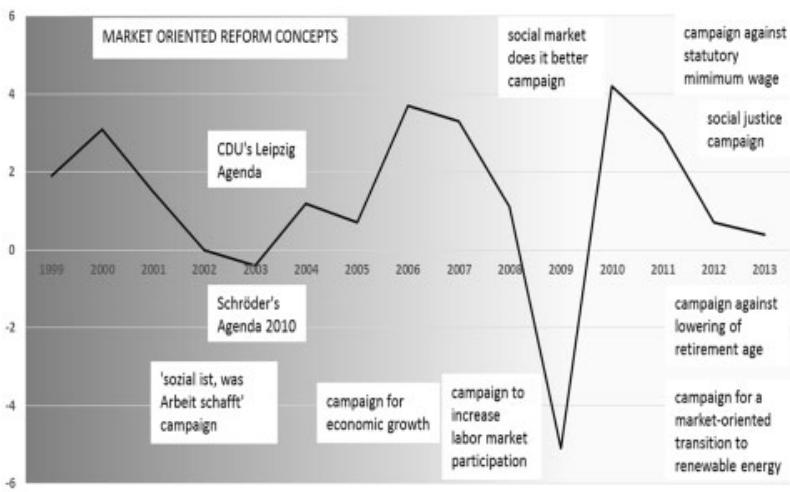

Figure 1 INSM campaigns and the economic growth rate.

Source: Statistisches Bundesamt (German Statistical Office)

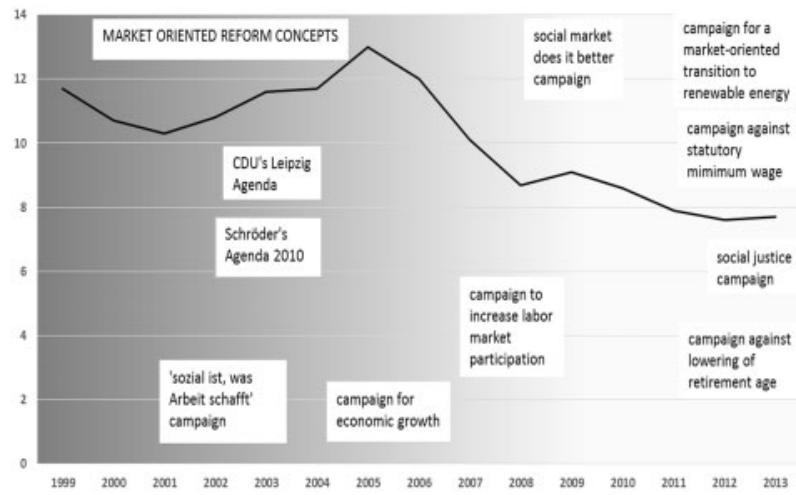

Figure 2 INSM campaigns and the unemployment rate.

Source: Statistisches Bundesamt (German Statistical Office)

persevere in the war of ideas over economic policy. This section also shows that the role of business in politics is not only an influencing but also an adaptive one. Although the purpose of the INSM is to change public opinion in accordance with business preferences, it must sometimes swim with the tide. It should be noted, however, that even during the phase of apparent moderation, when the INSM was on the defensive in the domestic realm, the INSM pushed for austerity policies, fiscal discipline and constitutionally based balanced-budget amendments at the European Union (EU) level during the Eurozone crisis (Kinderman, 2017). Next, I discuss what leading officials have to say about institutions.

\section{Why do employers prefer liberalization? Towards a more dynamic, conflictual and contested view of institutions}

My interviewees have diverse views on the usefulness of Germany's non-liberal institutions. They appreciate the benefits of wage moderation and a cooperative industrial relations 
culture and support the institution of co-determination up to a certain point: 'I think that most firms think that co-determination is good ... but only to a certain point. That point begins where the entrepreneur is no longer in control of his own decisions and has to ask the works council for approval' (Engemann, interview, 2013). Both Brocker and Engemann underline the importance of employer discretion, a point that is frequently neglected by VofC-inspired treatments of institutions that emphasize cross-class coalitions and the efficiency enhancing effects of CME institutions. The dynamic and unpredictable nature of global competition and the loose fit between institutions and company strategies may help explain my interviewees' universal emphasis on the need for ever-greater flexibility (Brocker and Fasbender and Rodenstock, interviews, 2013). The reforms of the 2000s are certainly helpful, but they have only partly succeeded in preventing a reduction in 'employers' freedom and autonomy. It is experiencing creeping erosion. That's the yeast in the dough (Fickinger, interview, 2012). Fasbender is more skeptical of the benefits of the German model:

What we produce here we can also produce in any other country. Today everything you can do in Germany you can also do pretty much anywhere else. The idea that 'it only works in Germany,' that idea is gone. Institutions in general may be useful - but this really depends on their specific manifestation. Not traditional institutions, but the reforms since the late 1990s have led to our current successes (interview, 2013).

Fasbender contradicts VofC in three ways. First, he denies that German employers derive competitive advantage from coordination. German companies can produce in Germany or elsewhere; they are not dependent on Germany's institutional framework. This points to a central weakness in the VofC literature: it provides little empirical support for the claim that German employers' production strategies and competitive success depend on Germany's CME institutions. There are many reasons to be skeptical of this claim: Germany's competitors have been gaining ground and price competition is increasing. Fleig remarks that 'Today one can build good cars anywhere' and that the quality of cars built outside of Germany is 'in no way' inferior to cars built in Germany (interview, 2015). In recent years, the German car industry has built more cars outside of Germany than it has in Germany. BMW's factory in Spartanburg, South Carolina has a larger capacity than any BMW factory in Germany.

Second, Fasbender implies that the extent to which institutions provide any competitive institutional advantage is variable, contextual and contingent. This is in line with recent work on the contestedness of institutions, which 'change dynamically all the time' (Witt and Jackson, 2016, p. 796), on incremental and slow-moving change, and in line with what we know about the transformation of codetermination from an instrument of workplace democracy to comanagement. Third, Fasbender charges that Germany's liberalizing reforms since the 1990s, rather than its non-liberal institutions, are responsible for the country's competitive resurgence. The figure below speaks to this claim.

Germany's competitive position has improved significantly since the mid-1990s, and dramatically since the mid-2000s. Germany's resurgence coincides with the liberalization of labor markets and collective bargaining institutions and the decentralization of the wagesetting process from the early 2000s onward (Dustmann et al., 2014, p. 168). One particular innovation was employers' associations' introduction of membership without being bound 
to collective bargaining agreements. These so-called OT memberships can be seen as a driving force for the dissolution of the coordinated market economy model (Haipeter, 2017). Germany's competitive advantage has benefited from these innovations (which coincide temporally with the INSM) and from the incorporation of 'hybrid institutional logics' (Witt and Jackson, 2016). The result of these reforms is that German firms are in a better position after liberalization than they were before it.

Looking at Figure 3, it is not hard to see why employers' associations' satisfaction with wage bargaining arrangements has increased. Germany's industrial relations system and broader institutional architecture has been restructured in the service of international competitiveness and employees, works councils and trade unions have made far-reaching concessions. It is these reforms-rather than traditional institutions-that are celebrated by the INSM. Even if some employers have failed to achieve their preferred objective of full-scale liberalization, Figure 3 suggests that their second-best alternative, a reengineering of the existing system, has served them very well during recent years. Given the dramatic improvement of Germany's macroeconomic and competitive position, it is not surprising that German employers have chosen to leave the wage bargaining system formally intact for the time being.

Through the INSM, employers have propagated, legitimated and facilitated marketoriented reforms in Germany's economy and society, and it is likely that the neoliberal ideas disseminated by the INSM have contributed to the increasing business-friendliness of German institutions and the cost competitiveness of German firms. The inherent asymmetry between liberalization and organization can help to explain why even firms that do not actively support the INSM agenda see no need to oppose it. As Paster (2012b) has argued, as long as voluntary practices remain viable, liberalization can accommodate critics as well as defenders of the institutional status quo, offering firms a menu of institutions to choose from.

Whereas in the mid-2000s, many German managers could not resist 'the enticing shores of a neoliberal market economy without corporatist obligations' (Streeck, 2005, p. 11), the

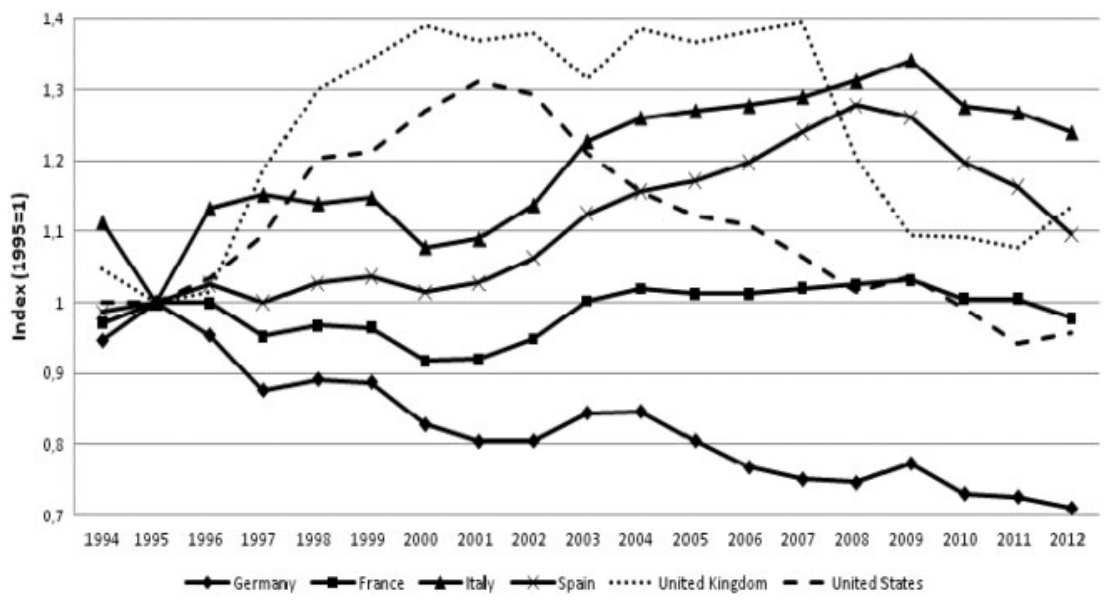

Figure 3 Evolution of competition-weighted relative unit labor costs, selected countries, 1994-2012. Source: Dustmann et al., p. 170 
Anglo-American model lost much of its allure with the financial crisis. The latter, together with wage moderation by organized labor may have led some critics who were enamored with the Anglo-American model to moderate their demands for liberalization. Perhaps they have even rediscovered the virtues of the new German model-the strengthening of the links between big firms and unions during the past 10 years could be an indication of this. However, social partnership remains 'contested' and employers' associations remain 'divided' over these arrangements (Behrens and Helfen, 2016, p. 352). Employer support for these arrangements will only persist as long as they are beneficial for German firms.

To what extent is this argument generalizable? The next section draws on insights from leading figures in Sweden's free-market movement to provide a comparative perspective.

\section{Timbro and the Swedish free-market movement}

Both Sweden and Germany are 'least-likely cases for liberalization'-yet 'neo-liberal ideas have achieved a surprising dominance in public debates' and 'Sweden has experienced a remarkable and sweeping "neo-liberalization"' (Schnyder and Jackson, 2013, pp. 313, 322). In response to the inability of bourgeois parties to 'repel the advances of socialism in the 1970s', Swedish employers began to promote an aggressive free-market agenda. In 1978, the SAF founded the think-tank Timbro-an 'uncompromising free market policy institute ${ }^{16}$ - to engage 'in theoretical and intellectual trench warfare' (Svanborg-Sjövall, 2012, pp. 5, 32). Although Timbro was founded over two decades before the INSM, the historical context is similar: lackluster economic performance and growing left-wing threats.

The LO's push for wage earner funds, wage equalization and economic democracy constrained employer discretion (Baccaro and Howell, 2017) and threatened private enterprise itself. In the 1970s, the Swedish business community faced a 'hugely disadvantageous strategic situation' (Hacker and Pierson, 2004, p. 189) but met these threats 'with fierce resistance'. ${ }^{17}$ 'The enemy has always been the socialist left', observes Janerik Larsson, who worked for the SAF for many years and is deeply familiar with Sweden's free-market movement. Larsson recalls that 'the wage earner funds helped to dramatize the threat but the single most important factor was the 1968 youth revolt. That is where it started' (interview, 2015). These threats 'had the effect of mobilizing and radicalizing employers' (Baccaro and Howell, 2017). In 1976, a few months before Curt Nicolin took over as SAF president, he gave a speech in which he said something memorable about 'power': 'Power is equated by many as the right to make decisions.' Nicolin criticized this view as giving a 'very meager picture of reality, because the right to make a decision is not in itself power. Real power is the ability to influence the course of events' (Larsson, 2013, p. 39). Over the next decades, the SAF would use discourse as a power resource to transform Sweden, and Timbro was an essential part of that project, as Mattias Bengtsson, one of Timbro's former presidents/CEOs explains:

The communications director of the SAF, Sture Eskilsson, and the chairman, Curt Nicolin, decided that there was a need for a think tank that not only said no to these changes, but instead was focused on a positive, pro-market agenda based on a broader ideological base defending

16 Svanborg-Sjövall, personal communication, October 16, 2015.

17 Mattias Bengtsson, personal communication, November 24, 2015 
private property, voluntary cooperation and a free and open society, i.e. liberalism in the European sense. Eskilsson was also inspired by British and American think tanks like the Institute of Economic Affairs, Cato and Heritage. ${ }^{18}$

In 1978, Nicolin used the Industry and Commerce Fund to fund Timbro 'as a symbol of a more ideological battle of ideas in the class struggle'. ${ }^{19}$ 'SVN and its predecessor, SAF, have always had a very long term and indirect focus when it's come to the support of Timbro', remarks former Timbro CEO and SVN communications director PJ Anders Linder. ${ }^{20}$ Although Timbro's budget of $\sim € 2.7$ million per year is smaller than the INSM's in absolute terms, it is significantly larger in relative terms. ${ }^{21}$ Representatives of the SVN and Timbro meet regularly to discuss strategy and public opinion and there is a 'very close relationship' between these two organizations. ${ }^{22}$ Timbro's annual grant from the Swedish Enterprise Foundation affords Timbro a measure of autonomy from direct business pressure. As a result, Timbro's agenda has been less issue-specific than the INSM, but like the latter it has been focused on economic freedom, tax levels and (de)regulation (Larsson, interview, 2015). ${ }^{23}$ Bengtsson recalls that 'a shift of economical-political system was the vision shared by many in the ruling bourgeoisie class at the time: lower taxes, less state ownership, deregulation, privatizations of public sector, reforms favoring entrepreneurship'. ${ }^{24}$ Early campaigns included 'Free Enterprise-Good for Sweden' and 'Invest in Yourself.' In addition to publishing classic libertarian texts, Timbro propagated a discourse of 'Suedosclerosis' to amplify the sense of crisis and delegitimize existing institutions.

The Swedish free-market effort has a 'very pro-Anglo Saxon mentality' (Larsson, interview, 2015), as the following examples show.

In 1980, SAF-economist Danne Nordling wrote on how Sweden should be privatized: 'It's really just the defense, police and the judiciary, and similar collective activities must be driven by the public sector. Everything else can be run by private companies' (Larsson, 2013, p. 91). Carl-Johan Westholm recalls when, in the mid-1980s, he came into the office and had scarcely sat down when Curt Nicolin told him 'that he had thought of during the weekend on what is necessary for a good society. First Freedom, he said'. ${ }^{25}$ Just how much economic freedom have Swedish employers been seeking, how far have they sought to push market-oriented reforms? According to Mats Johansson, former president/CEO of Timbro, 'The general answer is: as far as possible, whenever possible. ${ }^{26}$

18 personal communication, November 24, 2015.

19 Mats Johansson personal communication December 132015.

20 personal communication, November 13, 2015.

21 Once one controls for the size of the population and the economy.

22 Larsson, personal communication, September 19, 2015.

23 Timbro is only one of a number of organizations associated with the Confederation of Swedish Enterprise advocating free market reforms. Organizations with more issue specific agendas include Ratio and IFN.

24 Mattias Bengtsson, personal communication, November 24, 2015.

25 Westholm, personal communication, November 21, 2015.

26 Mats Johansson, personal communication, December 13, 2015. 
Like the INSM, Timbro has had devoted considerable effort to transforming the public sector and welfare policy, which has arguably contributed to a reduction of welfare benefits and the dismantling of public monopolies. Timbro introduced Milton Friedman's school voucher proposal into the Swedish public debate and became heavily involved in a battle for school choice and for independent and for-profit schools. ${ }^{27}$ Although the specific issue of childcare probably meant relatively little to Swedish employers, 'choice is an existential political question'. Timbro claims that its 'aggressive efforts ... to influence public opinion' in this realm helped pave the way for the 'freedom of choice revolution in social policy': a new service sector that had previously been under a strict public monopoly. This revolution 'shook up the political infrastructure in Sweden' and helped unleash 'a veritable tsunami of deregulation and privatization' (Svanborg-Sjövall, 2012, pp. 71, 75, 77, 79, 94). Furthermore, according to Markus Uvell, former Timbro CEO and SVN communications director,

The work carried out by Timbro ... has been of great importance in making the right to choose one of the most widely-held political beliefs in Sweden today. The profit motive is still being debated, but the fundamental principle that 'consumers' of these services should be given the right to choose is shared by more than $90 \%$ of the Swedish public. There's no going back from this, I believe this is a permanent shift. ${ }^{28}$

Timbro has focused on 'broadening the scope of the Swedish debate towards more pronounced free market ideas' and 'widening the perception of what is seen as "politically possible" in Sweden - thereby in effect shifting the "middle ground" in the Swedish public debate to the right'. ${ }^{29}$ Timbro has also sought to influence political parties:

A number of up and coming centre-right politicians have been part of the Timbro 'sphere.' The main target groups are young philosophically and ideologically interested individuals, especially those with academic, party political or journalistic ambitions. An example of this is the ideological development of especially the youth wings of the four Swedish centre-right parties: the Moderates, the Liberals, the Centre Party and the Christian Democrats. Timbro holds considerable sway among these activists ${ }^{30}$

Like the INSM in Germany, Timbro's successes in Sweden expose the 'political power of a clear narrative, particularly when embarking on new paths' (Svanborg-Sjövall, 2012, p. 35). Perhaps this is why current Timbro president/CEO Karin Svanborg-Sjövall characterizes Timbro as the 'revolutionary wing of the private sector' (2012, p. 95). As she put it to me, 'our mission has very clearly been to act as kind of a minesweeper in the public debate making previously unthinkable pro-market arguments accessible for others to hold: political parties, organizations or individual voters. ${ }^{31}$

27 The Moderate MP Per Unckel, who was active at Timbro in the 1980s, became minister of education in Carl Bildt's government and got the idea put in to practice. Today one fourth of Swedish high school attendees go to private schools. I am grateful to Mattias Bengtsson for this information.

28 personal communication, November 6, 2015.

29 Markus Uvell, personal communication, November 6, 2015.

30 Mattias Bengtsson, personal communication, November 24, 2015.

31 Svanborg-Sjövall, personal communication, October 5, 2015. 
As in Germany, multi-sectoral collective bargaining persists in Sweden. But it would be problematic to take this as evidence of employers' defense or dependence on coordination. Organized labor 'had to be dealt with in another way. To avoid open confrontation, disrupting relative co-operation to stand global competition and save jobs, union power had to be diluted, not abolished'. ${ }^{32}$ Since the establishment of Timbro, there has been a notable disjuncture between continuity in institutional form and continuity in institutional function: 'something dramatic has changed under the hood of Swedish industrial relations institutions ... as powerful liberalizing tendencies have transformed class relations and expanded the scope of employer discretion at the firm level' (Baccaro and Howell, 2017). Svallfors suggests that the 'ruins of the old corporatist social democratic edifice' have given way a new 'political power order' in which 'the relations between economic and political power have been restructured in a way consistent with the winner-take-all politics perspective' $(2015, \mathrm{p}$. 10). These outcomes are the result of Swedish employers being 'on the warpath' (Seikel, 2015, p. 1176) during recent decades.

In both Germany and Sweden, employers launched a counteroffensive in response to leftwing threats-but why did the German campaign for liberalization begin so much later than the Swedish one? Perhaps this delay is attributable to employers' defense of traditional institutions during the interim period? Hardly, consistent with prior research on unemployment insurance (Brosig, 2011) and job security regulations (Emmenegger and Marx, 2011) in Germany, I find that 'there were many reasons for [German] employers to take on the political establishment ${ }^{33}$ during the 1970s. In 1971, they tried to do this: the presidents of the BDI and BDA and 61 other leading business figures launched a large-scale advertising campaign-'wir können nicht länger schweigen,' 'we can no longer remain silent'-in daily newspapers in an attempt to prevent the reelection of Willy Brandy's SPD-FDP coalition government. This campaign was an utter failure: the SPD was reelected by the highest-ever margin and went on to pass the works constitution act (Betriebsverfassungsgesetz) in 1972. It took decades for German employers to regroup and acquire the PR expertise and financial resources necessary to launch the INSM.

In both Sweden and in Germany, employers did not end their push for liberalization once the left-wing threats had been defeated; employers continued their push for liberalization, toward an open-ended terminus. This comparison suggests that employers' quests for liberalization in Germany and Sweden have much in common: in each of these countries, employers founded neoliberal think-tanks which have campaigned aggressively for freemarket reforms and liberalization, privatization and deregulation. Indeed, it seems that there is nothing particularly cuddly about capitalists in Sweden-or perhaps anything particularly unique about the trajectory of these countries in comparison with the USA: in the 1970s, the American business elite and 'large firms began to aggressively attack both government regulation and organized labor' (Mizruchi, 2013, p. 270). This 'countermobilization by business conservatives' involved a 'systematic effort' to 'build counterinstitutions such as think tanks and other policy organizations'. The message of these think-tanks and policy organizations was that 'that salvation would come only from policies that restored the "natural order" of self-regulating markets' (Block, 2007, pp. 15, 19). The similarities are unmistakable. Johan Norberg, who has experience working for Timbro and the American libertarian Cato

32 Mattias Bengtsson, personal communication, November 24, 2015.

33 Volker Fasbender, personal communication, May 9, 2016. 
Institute, remarks that while some free marketers' in the USA are 'more hardcore' than in Sweden, he does not think these two organizations are that different: both strive for 'a general defence of free markets and limited government'. ${ }^{34}$

\section{Conclusion}

In an era of capital mobility and business power, the notion that different VofC 'operate according to different logics' (Hall and Thelen. 2009, p. 24) can only be sustained if employers in CMEs truly support and defend non-liberal institutions. VofC's 'reassuring' view of employer preferences (Thelen, 2014, p. xix) has contributed to its appeal and to its powerful influence in CPE. Through this article's analysis of employer-sponsored think-tanks in two critical archetype CMEs, I have argued VofC's understanding of employer preferences is flawed. German and Swedish employers' associations have not defended traditional institutional arrangements against liberalization as VofC proclaims. Instead, they have used discourse as a power resource to put pressure on these arrangements. While VofC stresses the imperative importance of non-market coordination for employers in CMEs, the INSM and Timbro have put wind in the sails of liberalization and advocated for more market coordination in virtually all areas of social and economic life. By the end of 2018, Gesamtmetall will have spent $\sim € 160$ million on the INSM, and Swedish employers will have spent $\sim € 100$ million on Timbro, an organization with an even more radical pro-free-market orientation. In both Sweden and Germany, left-wing threats, growing institutional constraints and poor macroeconomic performance radicalized employers and prompted them to find these thinktanks to propagate neoliberal ideas. The fact that German and Swedish employers have funded these aggressive pro-market campaigns casts doubt on arguments that 'business in Europe has generally kept its distance from the most aggressive versions of market fundamentalism' (Block, 2007, p. 26). For those on the left, the fact that these neoliberal campaigns began as responses to left-wing initiatives must leave a rather bitter aftertaste.

While the evidence presented in this article is imperfect, virtually everything about the INSM and Timbro supports PRT. These think-tanks' overall message is clear: a celebration, legitimation and defense of the unencumbered market, and a harsh critique of the welfare state. As Mudge points out, the 'elevation of the market ... over all other modes of organization' is neoliberalism's 'ideological core' (2008, p. 705). The burden of proof is on VofC to provide substantial empirical evidence and not merely theoretical speculation that employers in CMEs defend non-liberal institutions against liberalization.

Although this article has not been able to establish the precise impact of employersponsored neoliberal think-tanks on public policy, a growing literature suggests that these efforts have borne fruit: social solidarity has declined considerably in both Sweden and Germany (Fleckenstein and Lee, 2017), and Germany's welfare state and social policy have undergone a 'paradigmatic' and 'comprehensive' transformation. Social policy in Germany is now similar to the liberal welfare states of UK and USA and 'no longer warrants labeling Germany a conservative welfare state' (Seeleib-Kaiser, 2016, pp. 220, 235). The VofC literature has long recognized threats to non-liberal institutional arrangements, but these are seen as exogenous, coming from globalization or the EU. In this article, I have argued that these pressures are endogenous and come from the central actors in the system, employers 
themselves. Employers' strategies are versatile: even where they failed to retrench non-liberal institutions, the discourse of their neoliberal think-tanks has increased the pressure on public authorities, workers and citizens to tighten their belts and reengineer institutions from the perspective of economic efficiency. The literature's continuing preoccupation with formal institutional structure misses this big part of the action.

This article also sheds light on the INSM's changing orientation and strategy over time: from radical critiques of the German model and endorsements of LME-style institutions in the early 2000s to a defense of existing reform achievements during the past decade. In the first period, the INSM celebrated many victories; in the second, it sustained many defeats. I have argued that the INSM's moderation should be understood as a response to a growing anti-liberalization sentiment and electoral pressures rather than as employer support for the institutional status quo. In addition, improvements in firms' competitiveness, reductions in unit wage costs and the crisis of the Anglophone model can help explain the INSM's moderation.

Departing from the premise that both 'agents and their ideas matter' (Bell and Hindmoor, 2015, p. 340), future research should examine employer-sponsored think-tanks in other countries: why have neoliberal employer offensives against social policies occurred in some countries but not in others? ${ }^{35}$ It should also strive to explain the relationship between business power and business preferences (Paster, 2015) and the variation in employers' quests for liberalization across different issue areas, ${ }^{36}$ institutions ${ }^{37}$ and sectors. ${ }^{38}$ This research would benefit from careful conceptualization (Ornston and Schulze-Cleven, 2015) and the probing of causal mechanisms (Schulze-Cleven and Weishaupt, 2015).

This does not imply that employers are incessantly at war with market-constraining institutions. ${ }^{39}$ Taking a longer historical perspective, employer preferences may be malleable rather than stable. After far-reaching institutional reforms and concessions by employees and the crisis of Anglophone LMEs, and in the face of growing societal opposition, German employers have toned down their demands. But 'we cannot expect institutional stability as such ... the German labour market and the economy are undergoing further remodelling' (Eichhorst, 2015, p. 67). Following new welfare state largesse and the reregulation of labor markets, 'the discontentment of business is growing and a new Standortdebatte is taking place in German companies' (Hüther, interview, 2014). To understand these dynamics, liberalization theorists' view of capitalism and capitalists as unruly and disruptive provides a promising starting point.

35 See, for example, Paster's (2014) discussion of Austria.

36 Why has the INSM attacked many but not all elements of the welfare state and the institutional model German employers currently seem to support an expansion of family policy. In addition, they have not attacked the apprenticeship system.

37 According to Höpner and Waclawczyk (2012), co-determination enjoys a great deal of support among large German firms.

38 Here it is interesting to note that the German chemical industry employers $\mathrm{VCl}$ refused to support the INSM-perhaps because of its stronger commitment to social partnership or concern that doing so would jeopardize cooperative relations with unions.

39 See Etienne and Schnyder (2014) for a fascinating account of Swiss employers' role in non-liberal instutional change. 


\section{Interviews}

Ulrich Brocker. July 4, 2013.

Dietrich Creutzburg. August 8, 2013.

Hubertus Engemann. July 3, 2013.

Volker Fasbender. July 2, 2013.

Nico Fickinger. August 3, 2012.

Günther Fleig. April 7, 2015.

Max Höfer. July 12, 2014.

Max Höfer. July 30, 2013.

Max Höfer. August 8, 2012

Michael Hüther. August 19, 2014.

Janerik Larsson. November 12, 2015.

Hubertus Pellengahr. August 8, 2013.

Dieter Rath. June 11, 2014.

Dieter Rath. June 14, 2012.

Axel Rhein. June 11, 2014.

Randolf Rodenstock. July 22, 2013.

Hans Tietmeyer. July 27, 2006.

\section{Acknowledgments}

This article has been in the works for a long time, and it has benefitted greatly from generous insightful comments and suggestions from Matthew Allen, Lucio Baccaro, Ian Bruff, Anke Hassel, Martin Höpner, Chris Howell, Gregory Jackson, Thomas Paster, Dieter Plehwe, Alexander Reisenbichler, Sidney Rothstein, Vivien Schmidt, Tobias Schulze-Cleven, Martin Seeleib-Kaiser, Gerhard Schnyder, Stephen Silvia, and many others. The usual disclaimers apply.

\section{References}

Amable, B. (2016) 'Institutional Complementarities in the Dynamic Comparative Analysis of Capitalism', Journal of Institutional Economics, 12, 79-103.

Amable, B. and Palombarini, S. (2009) 'A Neorealist Approach to Institutional Change and the Diversity of Capitalism', Socio-Economic Review, 7, 123-143.

Balzer, A., Müller, H. and Rickens, C. (2008, August 29) 'Angela Merkel: Die Abkanzlerin', Manager Magazin.

Baccaro, L. and Howell, C. (2017) European Industrial Relations since the 1970s: Trajectories of Neoliberal Transformation, Cambridge, Cambridge University Press.

Baccaro, L. and Howell, C. (2011) 'A Common Neoliberal Trajectory: The Transformation of Industrial Relations in Advanced Capitalism', Politics \& Society, 39, 521-563

Behrens, M and Helfen, M. (2016) 'The Foundations of Social Partnership', British Journal of Industrial Relations, 54, 334-357

Bell, S. and Hindmoor, A. (2015) Masters of the Universe, Slaves of the Market, Cambridge, Harvard University Press.

Block, F. (2007) 'Understanding the Diverging Trajectories of the United States and Western Europe: A Neo-Polanyian Analysis', Politics \& Society, 35, 3-33.

Blyth, M. (2001) 'The Transformation of the Swedish Model: Economic Ideas, Distributional Conflict, and Institutional Change', World Politics, 54, 1-26. 
Bruff, I. (2008) Culture and Consensus in European Varieties of Capitalism: A 'Common Sense' Analysis, Basingstoke, Palgrave.

Brosig, M. (2011) 'Sozialpolitik als Hilfe für die Wirtschaft? Deutsche Arbeitgeber und die Systeme der Arbeitslosenunterstützung', Zeitschrift für Sozialreform, 57, 313-338.

Campbell, J. L. and Pedersen, O. K. (2015) 'Policy Ideas, Knowledge Regimes and Comparative Political Economy', Socio-Economic Review, 13, 679-701.

Campbell, J. L. and Pedersen, O. K. (2014) The National Origins of Policy Ideas, Princeton, Princeton University Press.

Clemens, C. (2007) 'Two Steps Forward, One Step Back: Merkel's CDU/CSU and the Politics of Welfare State Reform', German Politics, 16, 222-246.

Culpepper, P. (2016) 'Capitalism, Institutions, and Power in the Study of Business'. In Fioretos, O., Falleti, T, and Scheingate, A. (eds) The Oxford Handbook of Historical Institutionalism, Oxford, Oxford University Press, pp. 453-466.

Dustmann, C., Fitzenberger, B., Schönberg, U. and Spitz-Oener, A. (2014). 'From Sick Man of Europe to Economic Superstar: Germany's Resurgent Economy', Journal of Economic Perspectives, 28, 167-188.

Dyson, K. (2005) 'Economic Policy Management: Catastophic Equilibrium, Tipping Points and Crisis Interventions'. In Green, S. and Patterson, W. (eds) Governance in Contemporary Germany: The Semisovereign State Revisited, Cambridge, Cambridge University Press, pp. 115-137.

Eichhorst, W. (2015) 'The Unexpected Appearance of a New German Model', British Journal of Industrial Relations, 53, 49-69.

Emmenegger, P. and Marx, P. (2011) 'Business and the Development of Job Security Regulations: The Case of Germany', Socio-Economic Review, 9, 729-756.

Enzweiler, T. (2013) Wege aus dem Reformstau: Zentrale Determinanten bei der Akzeptanz wachstumsstärkender Strukturreformen, Berlin, Springer.

Etienne, J. and Schnyder, G. (2014) 'Logics of Action and Models of Capitalism: Explaining Bottom-up Non-Liberal Change', Swiss Political Science Review, 20, 365-387.

Fleckenstein, T. and Lee, S. (2017) 'The Politics of Labor Market Reform in Coordinated Welfare Capitalism: Comparing Sweden, Germany, and South Korea' World Politics .

Giaimo, S. (2001) 'Who Pays for Health Care Reform?' In Pierson, P. (ed.) The New Politics of the Welfare State, New York, Oxford University Press, pp. 334-364.

Hacker, J. and Pierson, P. (2004) 'Varieties of Capitalist Interests and Capitalist Power: A Response to Swenson', Studies in American Political Development, 18, 186-195.

Hahne, P. (2005, February 4) 'Die größten Jobvernichter der Bundesrepublik', Die Welt, pp. $12-13$.

Haipeter, T. (2017) 'Variety of Strategies. Arbeitgeberverbände ohne Tarifbindung in Deutschland', Zeitschrift für Politikwissenschaft, 26, 75-91.

Hall, P. and Thelen, K. (2009) 'Institutional Change in Varieties of Capitalism', Socio-Economic Review, 7, 7-34.

Hall, P. and Soskice, D. (2001) 'An Introduction to Varieties of Capitalism', In Hall, P. and Soskice, D. (eds) Varieties of Capitalism, Oxford, Oxford University Press, pp. 1-68.

Haselbach, D. (1997) 'Social Market Economy and West German Identity' In Zimmer, M. (ed.) Germany: Phoenix in Trouble?, Edmonton, University of Alberta Press, pp. 157-182.

Hassel, A. (2014) 'The Paradox of Liberalization - Understanding Dualism and the Recovery of the German Political Economy', British Journal of Industrial Relations, 52, 57-81.

Hassel, A. and Schiller, C. (2010) Der Fall Hartz IV: Wie es zur Agenda 2010 kam und wie es weitergeht, Frankfurt, Campus.

Hay, C. (1996) Narrating Crisis: The Discursive Construction of the 'Winter of Discontent', Sociology, 30, 253-277. 
Höfer, M. (2013) Vielleicht will der Kapitalismus gar nicht, dass wir glücklich sind?, Munich, Knaus.

Höfer, M. (2010) 'Externalisierung der Verbandskommunikation: die Initiative Neue Soziale Marktwirtschaft', In Hoffjan, O. and Stahl, R. (eds) Handbuch Verbandskommunikation, Wiesbaden, VS, pp. 21-28.

Höpner, M. and Waclawczyk, M. (2012) 'Opportunismus oder Ungewissheit? Die Arbeitgeberhaltungen zum mitbestimmten Aufsichtsrat', Industrielle Beziehungen, 19, 314-336.

Howell, C. (2015) 'Review Symposium On Kathleen Thelen, Varieties of Liberalization and the New Politics of Social Solidarity', Socio-Economic Review, 13, 399-403.

Initiative Neue Soziale Marktwirtschaft (2009) 'Die Kommunikation der Initiative Neue Soziale Marktwirtschaft, 2000-2009’ Internal Documentation.

Initiative Neue Soziale Marktwirtschaft (2005a) Initiative!Direkt, Cologne, INSM.

Initiative Neue Soziale Marktwirtschaft (2005b) Vision D: Der Wohlstand hat Zukunft, Cologne, Deutscher Instituts, 2005.

Kessler, M. (2011, November 14) 'Die 180-Grad-Drehung der CDU', Rheinische Post.

Kinderman, D. (2017) 'The Initiative for a New Social Market Economy and the Transformation of the German Welfare Regime after Unification'. In Backhouse, R., Bateman, B., Nishizawa, T. and Plehwe, D. (eds) Liberalism and the Welfare State: Economists and Arguments for the Welfare State, Oxford, Oxford University Press.

Kinderman, D. (2014) 'Challenging Varieties of Capitalism's Account of Business Interests The New Social Market Initiative and German Employers' Quest for Liberalization, 2000-2014', MPIfG Discussion Paper 14/16. Cologne: Max Planck Institute for the Study of Societies Discussion Paper 14/16.

Kinderman, D. (2005) 'Pressure from Without, Subversion from Within: the Two-Pronged German Employer Offensive', Comparative European Politics, 3, 432-463.

Korpi, W. (2006) 'Power Resources and Employer-Centered Approaches in Explanations of Welfare States and Varieties of Capitalism: Protagonists, Consenters, and Antagonists', World Politics, 58, 167-206.

Larsson, J. (2013) Så förändrades Sverige - företagarrörelsen och opinionen, Stockholm, Timbro.

Mares, I. (2003) The Politics of Social Risk: Business and Welfare State Development, New York, Cambidge University Press.

Merz, F. (2003) 'Die Zeit ist reif für eine wirklich große Einkommensstenerreform', Cologne, Chancen für alle.

Metzger, O. (2003) 'Nutzt das Fenster für Reformen', Handelsblatt 21.3.

Mizruchi, M. (2013) The Fracturing of the American Corporate Elite, Cambridge, Harvard University Press.

Nölke, A. and Vliegenthart A. (2009) 'Enlarging the Varieties of Capitalism: The Emergence of Dependent Market Economies in East Central Europe', World Politics, 61, 670-702.

Mudge, S. (2008) 'What is Neo-liberalism?', Socio-Economic Review, 6, 703-731.

Ornston, D. and Schulze-Cleven, T. (2015). 'Conceptualizing Cooperation: Coordination and Concertation as Two Logics of Collective Action', Comparative Political Studies, 48, 555-558.

Paster, T. (2015) 'Bringing Power Back In: A Review of the Literature on the Role of Business in Welfare State Politics', MPIfG Discussion Paper 15/3, Cologne.

Paster, T. (2013) 'Business and Welfare State Development: Why Did Employers Accept Social Reforms?', World Politics, 65, 416-451.

Paster, T (2012a) The Role of Business in the Development of the Welfare State and Labor Markets in Germany: Containing Social Reforms, Abingdon, Routledge.

Paster, T. (2012b) 'Do German Employers Support Board-level Codetermination? The Paradox of Individual Support and Collective Opposition’, Socio-Economic Review, 10, 471-495. 
Paster, T. (2014) 'Why Did Austrian Business Oppose Welfare Cuts? How the Organization of Interests Shapes Business Attitudes Toward Social Partnership' Comparative Political Studies, 47, 966-992.

Ptak, R. (2009) 'Neoliberalism in Germany: Revisiting the Ordoliberal Foundations of the Social Market Economy'. In Mirowski, P. and Plehwe, D. (eds) The Road from Mont Pèlerin: The Making of the Neoliberal Thought Collective, Cambridge, Harvard University Press, pp. 98-138.

Rodenstock, R. (2001) Chancen für Alle: Die Neue Soziale Marktwirtschaft, Cologne, Deutscher Instituts-Verlag.

Schmidt, V. and Thatcher, M. (2013) 'Theorizing Ideational Continuity: The Resilience of Neo-liberal Ideas in Europe' In Schmidt, V. and Thatcher, M. (eds) Resilient Liberalism in Europe's Political Economy, New York, Cambridge University Press, pp. 1-50.

Schmidt, V. (2010) 'Taking Ideas and Discourse Seriously: Explaining Change Through Discursive Institutionalism as the Fourth "new institutionalism", European Political Science Review, 2, 1-25.

Schnyder, G., and Jackson, G. (2013) 'Germany and Sweden in the Crisis: Re-coordination or Resilient Liberalism?'. In Schmidt, V. and Thatcher, M. (eds) Resilient Liberalism in Europe's Political Economy, New York, Cambridge University Press, pp. 313-344.

Schulze-Cleven T. and Weishaupt T. (2015) 'Playing Normative Legacies: Partisanship and Employment Policies in Crisis-Ridden Europe', Politics \& Society, 43, 269-299.

Seeleib-Kaiser, M. (2016) 'The End of the Conservative German Welfare State Model', Social Policy \& Administration, 50, 219-240.

Seikel, D. (2015) 'Class Struggle in the Shadow of Luxembourg. The Domestic Impact of the European Court of Justice's Case Law on the Regulation of Working Conditions', Journal of European Public Policy, 22, 1166-1185.

Silvia, S. (2013) Holding the Shop Together: German Industrial Relations in the Postwar Era, Ithaca, Cornell University Press.

Speth, R. (2004) 'Die politischen Strategien der Initiative Neue Soziale Marktwirtschaft', Arbeitspapier 96. Düsseldorf: Hans-Böckler-Stiftung.

Streeck, W. (2009) Re-Forming Capitalism, Oxford, Oxford University Press.

Streeck, W. (2005) 'Nach dem Korporatismus: Neue Eliten, neue Konflikte', MPIfG Working Paper 05/4, May 2005.

Streeck, W. (2014) Buying Time: The Delayed Crisis of Democratic Capitalism, London, Verso.

Svanborg-Sjövall, K. (2012) Private Choice in the Public Sector: The New Swedeish Welfare Model, Stockholm, Timbro.

Svallfors, S. (2015) 'Politics as Organized Combat New Players and New Rules of the Game in Sweden', MPIfG Discussion Paper 15/2, Cologne.

Thelen, K. (2014) Varieties of Liberalization and the New Politics of Social Solidarity, New York, Cambridge University Press.

Thelen, K. (2010) 'Economic Regulation and Social Solidarity: Conceptual and Analytic Innovations in the Study of Advanced Capitalism', Socio-Economic Review, 8, 187-207.

Tietmeyer, H. (2001) Die soziale Marktwirtschaft erneuern, Cologne, Chancen für alle.

Tietmeyer, H. (2003) 'Treibt die Reformen voran!' Handelsblatt 21.2.

van Suntum, U. (2006) Masterplan Deutschland: Mit dem Prinzip Einfachheit zurück zum Erfolg, Munich, Deutscher Taschenbuch.

Witt, M. and Jackson, G. (2016) 'Varieties of Capitalism and Institutional Comparative Advantage: A test and Reinterpretation', Journal of International Business Studies, 47, 778-806.

Wood, S. (2001) 'Labour Maket Regimes under Threat? Sources of Continuity in Germany, Britain and Sweden'. In Pierson, P. (ed.) The New Politics of the Welfare State, New York, Oxford University Press, pp. 368-409. 